EMILIA SZYMCZAK

Uniwersytet im. Adama Mickiewicza

$w$ Poznaniu

\title{
HEJTING \\ JAKO PRZYKŁAD WSPÓŁCZESNEGO ZAGROŻENIA W PRZESTRZENI SPOŁECZNEJ
}

ABSTRACT. Szymczak Emilia, Hejting jako przykład wspótczesnego zagrożenia w przestrzeni społecznej [Hating as an Example of Contemporary Threats in Social Space]. Studia Edukacyjne nr 37, 2015, Poznań 2015, pp. 91-107. Adam Mickiewicz University Press. ISBN 978-83-232-2967-4. ISSN 12336688. DOI: $10.14746 /$ se.2015.37.7

In contemporary constantly changing world, which opens a network of contacts and cares about the anonymity of its users, we often experience hate speech, which is gradually gaining momentum in the form of increasingly sophisticated and at the same time less and less subtle forms of communication. Hate and trolling are concepts that are currently popular forms of psychological violence. The subject of this article is hate speech, in other words verbal aggression, criticism and widely understood negation, which take place in relation to other people and their actions. The aim of this article is to present the meaning and extent of this phenomenon based on theoretical sources and available studies.

Key words: hate speech, hate, verbal aggression, social inequalities, internet, media

We współczesnym, nieustannie zmieniającym się i stechnologizowanym świecie, otwierającym sieci kontaktów i dbającym o anonimowość swoich użytkowników, niejednokrotnie możemy spotykać się z mową nienawiści, która wydawać by się mogło sukcesywnie przybiera na sile pod postacią coraz bardziej wyrafinowanych i zarazem coraz mniej subtelnych form przekazu1. Hejting (w wolnym tłumaczeniu: nienawidzenie wszystkiego i wszystkich), trolling (w wolnym tłumaczeniu: wyśmiewanie i obrażanie

${ }^{1}$ J. Pyżalski, Agresja elektroniczna dzieci i młodzieży - różne wymiary zjawiska, Kwartalnik Dziecko Krzywdzone, 2009, 1(26), s. 13. 
innych) to jedynie wybrane pojęcia, które stanowią popularne obecnie formy przemocy psychicznej. Odnoszą się one głównie do słownej agresji, krytyki i szeroko pojętej negacji mającej miejsce w stosunku do innych osób oraz ich działań (w szczególności pojęcie to odnosi się do negatywnych, obraźliwych komentarzy $\mathrm{w}$ przestrzeni Internetu wystosowywanych do uczestników forów, blogów i stron internetowych), jednak sposób i zasięg działania hejtu - określenia stosowanego na nienawistne, obrażające komentarze, komunikaty, treści - przybiera różne postaci i jest o wiele bardziej złożony.

Problem nierówności społecznych i przemocy nie jest problemem nowym. Z punktu widzenia antropologii, świat społeczny niemalże od zawsze skonstruowany był na bazie licznych form władzy² i dominacji określonych grup społecznych, które odciskały swoje piętno na społecznościach zdominowanych i w konsekwencji były powodem społecznych nierówności, dysproporcji i wielości konfliktów pomiędzy nimi ${ }^{3}$. Określony kontekst historyczny i kultura danego kraju czy społeczeństwa lokalnego nierzadko dodatkowo prowadziły do powstania w świadomości społecznej silnie zinternalizowanych z pokolenia na pokolenie uprzedzeń i stereotypów ${ }^{4}$. Problem nierówności społecznych dotyka również $\mathrm{w}$ dużym stopniu zagadnienia wielokulturowości, polityki asymilacyjnej, praw mniejszości i ich udziału w życiu społecznym danego regionu ${ }^{5}$.

Podążając dalej, współczesny świat, a w nim rozwój technologiczny i wzrost anonimowości, otwiera drogę do nawiązywania, w błyskawicznym czasie, znajomości oraz rozpowszechniania dowolnych treści i przekazów ${ }^{6}$, co $\mathrm{w}$ konsekwencji, za sprawą jego niemalże nieograniczonego dostępu i trudności związanych z identyfikacją użytkowników, uaktywnia/umożliwia o wiele więcej form przemocy i sposobów znęcania się nad innymi ludźmi. Współczesne media społeczne (social media) stają się coraz częściej głównym źródłem nabywania wiedzy o świecie, biorą udział w procesie

2 M. Foucault, Trzeba bronić społeczeństwa, Wykłady w College de France 1976, przekł. M. Kowalska, Warszawa 1998, s. 31.

${ }^{3}$ B. Szacka, Wprowadzenie do socjologii, Warszawa 2003, s. 277.

4 Geneza hejtu, http://uprzedzuprzedzenia.org/czym-mowa-nienawisci/geneza-hejtu/, [dostęp: 15.10.2015].

${ }_{5}$ Polska w ruchu. Eksperci i młodzi liderzy o wielokulturowości transformacji i aktywizmie, Warszawa 2014, s. 58-88, źródło: http://uprzedzuprzedzenia.org/wp-content/uploads/2015/08/ Polska-w-Ruchu_PL.pdf, [dostęp: 15.10.2015].

${ }^{6}$ A. Gromkowska-Melosik, Tożsamość w cyber-przestrzeni - (re)konstrukcje i (re)prezentacje, Kultura Współczesna, 1999, 3(21), s. 37.

7 N.D. Gitari i in., A Lexicon-based Approach for Hate Speech Detection, International Journal of Multimedia and Ubiquitous Engineering, 2015, 10, 4, p. 215-216. 
uspołeczniania jednostki, jej rozwojư ${ }^{8}$, jak również wpływają na kształtowanie się umiejętności komunikacyjnych korzystających z nich jednostek oraz sposoby budowania, nawiązywania, podtrzymywania i charakteru relacji społecznych ${ }^{9}$. Stanowić mogą w ten sposób silną dźwignię wpływu oddziałującą na kolejne pokolenia młodzieży, ale także osób dorosłych i dzieci. Dlatego też, zagrożenia płynące z tego świata i ich sukcesywne niwelowanie jest dziś tak ważne. Czym jest zatem mowa nienawiści, hejt i jakie formy przyjmuje?

Mowa nienawiści (ang. hate speech) dotyczy sytuacji związanych z podżeganiem do nienawiści ${ }^{10}$ i definiowana jest jako przejaw innych zjawisk społecznych, np.: nietolerancji, ksenofobii, rasizmu, nierówności społecznych, czy dyskryminacji. Polega ona

na używaniu języka w celu rozbudzenia, rozpowszechniania czy usprawiedliwiania nienawiści i dyskryminacji, jak również przemocy wobec konkretnych osób, grup osób, przedstawicieli mniejszości czy jakiegokolwiek innego podmiotu będącego „na celowniku” danej wypowiedzi11.

Ze strony www.mowanienawiści.info (powstałej w ramach programu „Obywatele dla Demokracji”, finansowanego z Funduszy EOG) dowiadujemy się, iż pojęcie to rozumiane jest jako

nawoływanie do nienawiści, groźby czy obelgi o motywacji rasistowskiej czy ksenofobicznej, [definiowane jest jako - E.S.] język nienawiści, dyskurs dyskryminacyjny; czasem mowę nienawiści sytuuje się bliżej stereotypów i uprzedzeń, a czasem bliżej działań, w których wyraźny jest akt nawoływania do nienawiści, istotne są intencje sprawcy ${ }^{12}$.

\section{W takim rozumieniu mową nienawiści może być}

jakakolwiek wypowiedź, gest lub zachowanie, pismo czy przekaz, które są zabronione, ponieważ mogą podburzać do przemocy lub szkodliwego działania przeciw

8 The Cybersmile Foundation, Corporate Partnership Programme 2015, s. 3, https://www. cybersmile.org/wp-content/uploads/Cybersmile-Corporate-Programme-20151.pdf, [dostęp: 15.10.2015].

9 D.M. Law i in., The changing face of bullying: An empirical comparison between traditional and internet bullying and victimization, Computers in Human Behavior, 2012, 28, s. 226.

10 A. Weber, Manual on hate speech, Strasburg 2009, s. 3-4.

11 Czym jest mowa nienawiści, źródło: http://uprzedzuprzedzenia.org/czym-mowanienawisci/, [dostęp: 15.10.2015].

12 Mowa nienawiści, źródło: http://www.mowanienawisci.info/post/570/, [dostęp; 15.10.2015]. 
chronionej jednostce lub grupie albo dyskredytują lub zastraszają chronioną jednostkę lub grupę 13 .

S. Kowalski i M. Tulli uważają przy tym, że jest to „każda wypowiedź lżąca, wyszydzająca i poniżająca jednostki bądź grupy"14, natomiast E. Ryłko rozumie mowę nienawiści jako „różne typy emocjonalnie negatywnych wypowiedzi, wymierzonych przeciwko grupom, które opisuje się jako "'gorsze'"15. Soczewką skupiającą wielość definicji funkcjonujących w ramach tego zagadnienia jest Rada Europy, która przyjmuje, iż pod pojęciem mowa nienawiści kryją się

wszystkie formy wypowiedzi, które szerzą, propagują, wspierają i usprawiedliwiają nienawiść rasową, ksenofobię, antysemityzm lub [są to - E.S.] inne formy nienawiści oparte na nietolerancji, w tym: nietolerancja wyrażona przez agresywny nacjonalizm i etnocentryzm, dyskryminacja i wrogość wobec mniejszości, imigrantów i osób obcego pochodzenia ${ }^{16}$.

Poprzez stosowanie mowy nienawiści mamy do czynienia ze zjawiskiem postępującego zaogniania, zaostrzania funkcjonujących w świecie społecznym antagonizmów. Niekiedy może ona być przyczynkiem do powstania innych zjawisk i przestępstw, tzw. hate crimes, u podłoża których leży antypatia, nienawiść, funkcjonujące stereotypy, uprzedzenia i nierówności17. Zdaniem Organizacji Bezpieczeństwa i Współpracy w Europie (Office for Democratic Institutions and Human Rights - ODIHR), przestępstwa z nienawiści to

każde przestępstwo natury kryminalnej, wymierzone w ludzi i ich mienie, w wyniku którego ofiara lub inny cel przestępstwa są dobierane ze względu na ich faktyczne bądź domniemane powiązanie lub udzielanie wsparcia grupie wyróżnianej na podstawie cech charakterystycznych wspólnych dla jej członków, takich jak faktyczna lub domniemana rasa, narodowość lub pochodzenie etniczne, język, kolor skóry, religia, płeć, wiek, niepełnosprawność fizyczna lub psychiczna, orientacja seksualna lub inne podobne cechy ${ }^{18}$.

13 Jak zamalowywać hejty? Podręcznik, s. 4., źródło: http://news.hejtstop.pl/wp-content/ uploads/2015/05/podrecznik_165x240_web.pdf, [dostęp: 15.10.2015].

${ }^{14}$ S. Kowalski, M. Tulli, Zamiast procesu. Raport o mowie nienawiści, Warszawa 2003, s. 21.

${ }^{15}$ E. Ryłko, Jak mówić o przestępstwach z nienawiści? [w:] Przemoc motywowana uprzedzeniami. Przestępstwa z nienawiści, red. A. Lipowska-Teutsch, E. Ryłko, Warszawa 2007, s. 11.

16 Recommendation No. R (97) 20 of The Committee of Ministers to Member States on "Hate Speech", Council of Europe, s. 107, źródło: http://www.coe.int/t/dghl/standardsetting/ hrpolicy/other_committees/dh-lgbt_docs/CM_Rec(97)20_en.pdf, [dostęp: 15.10.2015].

17 Czym jest mowa nienawiści.

${ }^{18}$ Podaję za: E. Ryłko, Jak mówić o przestępstwach z nienawiści? s. 11. 
Bezpośrednio z mową nienawiści związane jest wyrażenie hejt, które pochodzi od angielskiego słowa hate, co oznacza nienawiść/nienawidzić. Osoba, która dopuszcza się negatywnych komentarzy/przekazów w stosunku do innych osób nazywana jest powszechnie hejterem.

Najczęściej spotykane przestrzenie, według strony internetowej uprzedzuprzedzenia.org - prowadzonej z ramienia Fundacji Humanity in Action Polska, w których hejterzy znajdują pole do urzeczywistniania swoich działań, stanowią wspomniane już media, Internet, przestrzeń publiczna (jako napisy i hasła na murach, obraźliwe w swej treści murale oraz graffiti), jak również najbliższe otoczenie społeczne (w postaci bezpośrednio artykułowanych $\mathrm{w}$ interakcji $\mathrm{z}$ drugą osobą opinii, komentarzy, czy haseł). Z kolei, do najczęściej hejtowanych w Polsce grup zaliczyć można: mniejszości nieheteronormatywne, osoby czarnoskóre, mniejszość romską i mniejszość żydowską oraz uchodźców. Te oraz inne antagonizmy funkcjonują w przestrzeni społecznej $\mathrm{w}$ obrębie szeregu powszechnie znanych zjawisk, jak: antysemityzm, transfobia ${ }^{19}$, romofobia, rasizm, ksenofobia, szowinizm, islamofobia, homofobia, chrystianofobia i ateizm ${ }^{20}$.

Zespół ds. Ochrony Praw Człowieka donosi, że w roku 2014 liczba spraw dotyczących przestępstw $\mathrm{z}$ nienawiści wynosiła prawie dwa razy tyle co w roku 2013 (315 przypadków w roku 2014 i 175 w roku 2013), z czego najwięcej dotyczyło kwestii rasowych, etnicznych i pochodzenia społecznego (223) ${ }^{21}$. Badania opinii społecznej ukazują, iż $40 \%$ Polaków co najmniej raz $\mathrm{w}$ swoim życiu zetknęło się z mową nienawiści, co może świadczyć, że jest to ważny współcześnie problem społeczny. Ponadto, $78 \%$ badanych osób przyznaje, że czuje dyskomfort, kiedy spotyka się z dyskryminującymi treściami i obraźliwymi komentarzami w przestrzeni publicznej, nawet jeśli nie dotykają one bezpośrednie grupy społecznej, z którą dane osoby się identyfikują22. Także Fundacja Dzieci Niczyje - na co zwraca uwagę Joanna Włodarczyk - przeprowadziła badania, w ramach projektu EU NET ADB, w których stwierdzono, że 40\% młodych ludzi w wieku 14-17 lat spotkało się $\mathrm{w}$ Internecie ze zjawiskiem mowy nienawiści (negatywne komentarze i obraźliwe dyskusje). W przypadku młodzieży w wieku 16-17 lat świadkiem takich incydentów było $45 \%$ osób. Na bazie przeprowadzonych badań stwierdzono również, że osoby doświadczające takich przekazów wykazy-

${ }^{19}$ Zjawisko polegające na dyskryminacji osób transpłciowych.

${ }^{20}$ Czym jest mowa nienawiści.

${ }^{21}$ Dotknięci przez nienawiść, zapomniani przez prawo. Brak spójnego systemu zwalczania przestęstw z nienawiści w Polsce, Amnesty International, 2015, s. 55.

${ }_{22}$ Centrum Badania Opinii Społecznej, Społeczna percepcja przemocy werbalnej i mowy nienawiści. Komunikat z badań, Warszawa 2007, s. 2-3. 
wały się większymi skłonnościami do przejawiania zachowań lękowych i depresji23. W raporcie z badań sondażowych "Mowa nienawiści”, przeprowadzonych przez Fundację im. Stefana Batorego w 2014 roku, odnajdziemy informacje, że:

w przypadku młodzieży akceptacja mowy nienawiści wynika w większym stopniu z uprzedzeń aniżeli z umiłowania wolności słowa. Akceptacja mowy nienawiści nie jest jednak kolejnym przejawem wzrastającej agresji w języku - młodzież o wyższym poziomie agresji językowej niekoniecznie popiera mowę nienawiści²4.

O rosnącej sile tego zjawiska świadczy także raport firmy McAfee (IntelSecurity) z 2014 roku, w którym 87\% młodzieży przyznało, iż było świadkiem cyberprzemocy. Dla porównania, w badaniach prowadzonych rok wcześniej takich osób było $27 \% 25$. Sama młodzież, o czym świadczą badania opublikowane przez The Children's Research Centre (CRC; Open University) przyznaje (78\%), że zjawisko przemocy i nadużyć w przestrzeni Internetu sukcesywnie wzrasta na sile i poszerza swój zasięge' ${ }^{26}$. Fundacja Cybersmile z okazji dnia pod hasłem: Stop Cyberprzemocy (ang: Stop Cyberbullying Day) w 2015 roku przeprowadziła we współpracy z Sugarscape badania, w których zapytano 2800 młodych ludzi o nadużycia w przestrzeni cyfrowej. Na pytanie, ile razy byłeś świadkiem nadużyć w Sieci ponad połowa respondentów (55\%) przyznało, że spotkała się z tym zjawiskiem, przy czym $8 \%$ osób podkreśliło, że ilość takich incydentów była tak duża, że przestali liczyć. Wśród portali internetowych, z których korzysta dzisiejsza młodzież, takich jak: Facebook, Twitter, Ask.Fm, Instagram, Tumblr, Snapchat, Google+ najbardziej „popularnym” (wśród badanych osób) pod względem liczby zaobserwowanych zjawisk przemocy okazał się Facebook (wskazało na niego 35\% respondentów). Najwięcej respondentów (45\%) wskazało też na konieczność stosowania wobec osób dopuszczających się przemocy w Sieci

${ }^{23} \mathrm{~J}$. Włodarczyk, Mowa nienawiści w Internecie w doświadczeniu polskiej młodzieży, s. 3, źródło: http://www.mowanienawisci.info/wp-content/uploads/2014/10/Mowa-nienawi\%C5 \%9Bci-w-internecie-w-do\%C5\%9Bwiadczeniu-polskiej-m\%C5\%82odzie\%C5\%BCy.pdf, [dostęp: 15.10.2015].

${ }^{24}$ M. Bilewicz i in., Mowa nienawiści. Raport z badań sondażowych, Warszawa 2014, s. 7.

25 McAfee, Teens and the Screen study: Exploring Online Privacy, Social Networking and Cyberbullying, 2014, źródło: http://www.mcafee.com/us/about/news/2014/q2/2014060301.aspx, [dostęp: 15.10.2015].

26 S. Tarapdar, M. Kellett, Young People's Voices On Cyberbulling: What can age comparisons tell us? Report 2011, Diana Award, s. 25. źródło: http://oro.open.ac.uk/32271/1/Diana__Young_Peoples_Voices_Report.pdf, [dostęp: 15.10.2015]. 
alternatywnych kar, w postaci np. prac społecznych, które mogłoby ustrzec innych przed popełnianiem podobnych czynów w przyszłości27.

Zjawisko hejtu, a w nim poziom niezadowolenia społecznego, może być potęgowane przez trzy grupy ludzi. Pierwszą z nich jest społeczność charakteryzująca się „wysokim poziomem orientacji na dominację społeczną” 28. Są to osoby przeświadczone o swojej wyższości nad innymi ludźmi, wierzące w podziały międzyludzkie, konieczność dominacji, wyższość jednej grupy nad inną i tym samym przymus podporządkowania się słabszych grupie dominującej. Wierzą oni $\mathrm{w}$ to, że powodzenie i ogólna satysfakcja z życia należy się osobom o naturze dominującej, twardo stąpającym po ziemi, którzy sukcesywnie i skutecznie eliminują słabszych przeciwników. Nie mają oni z reguły współczucia dla osób bezbronnych, biednych. Na podstawie przeprowadzonych badań odnośnie mowy nienawiści w Polsce w 2014 roku (M. Bilewicz, M. Marchlewska, W. Soral, M. Winiewski) stwierdzono, że osoby szczególnie silnie hejtujące określone grupy społeczne w pewien sposób „odwrażliwiają się”, tj.

przestają dostrzegać obraźliwość nawet najbardziej brutalnych jej przykładów. Co więcej, zmieniają też swój stosunek do mniejszości i zaczynają unikać ich w swoim otoczeniu. Jest to [jak wskazują autorzy - E.S.] wysoka cena mowy nienawiści ${ }^{29}$.

Kolejna, druga grupa hejterów to anonimowa ${ }^{30}$ społeczność przestrzeni online. Mam tutaj na myśli użytkowników Internetu, którzy dopuszczają się niekiedy bardzo agresywnych, dosadnych i mocnych w swej treści komentarzy, przy jednoczesnym bardzo skrupulatnym ukrywaniu własnej tożsamości ${ }^{31}$ za płaszczem nierealnych, fikcyjnych nicków (pseudonimów wykorzystywanych w przestrzeni Internetu), nazw i e-maili. Odnosi się to również do nieograniczonego potencjału Internetu w zakresie możliwości nieustannego rekonstruowania własnej tożsamości zgodnie z przyjętymi w danym momencie założeniami i intencjami. Jak zauważa A. Gromkowska-Melosik, w cyberprzestrzeni ,jednostka nabiera przekonania, iż - poprzez dostęp do

27 Stop Cyberbullying Day, Annual Research, 2015, https://www.cybersmile.org/wpcontent/uploads/Stop-Cyberbullying-Day-2015-Annual-Report.pdf, [dostęp: 15.10.2015].

28 A. Stefaniak, M. Bilewicz, Polska: wyzwania. Mowa nienawiści jako studium przypadku, [w:] Polska w ruchu. Eksperci i młodzi liderzy o wielokulturowości, transformacji i aktywizmie, Warszawa 2014, s. 78.

${ }^{29}$ Tamże.

${ }^{30} \mathrm{~K}$. Krejtz, Poziom kultury wypowiedzi internetowych i jego determinanty - wnioski z analizy treści wpisów polskich internautów, [w:] Internetowa Kultura Obrażania? red. K. Krejtz, Ośrodek Przetwarzania Informacji 2012, s. 25-26, źródło: http://www.komentujnieobrazaj.pl/kno/koraport.pdf, [dostęp: 15.10.2015].

31 J. Włodarczyk, Mowa nienawiści w Internecie, s. 9. 
nieograniczonych źródeł Internetu - uwalnia się od społecznych ograniczeń i społecznej kontroli, zyskując $\mathrm{w}$ ten sposób władzę autokreacji" ${ }^{32}$. To wszystko sprawia, że możemy czuć się w niej niekiedy niemalże bezkarni, co niesie za sobą prawdopodobieństwo, iż w przestrzeni tej będziemy dopuszczać się czynów i prezentować takie treści, których w świecie realnym nigdy byśmy na głos nie wypowiedzieli. Owa „epidemia tożsamości”33 jakiej doświadczamy w przestrzeni wirtualnej ośmiela nas, nasze działanie, gdyż w każdym momencie związane jest $\mathrm{z}$ tą bezpieczną świadomością, iż za chwilę (np. po zmianie nicku) można stać się kimś zupełnie innym.

Trzecim wyróżnionym typem hejterów, obejmującym aspekt politycznoekonomiczny, jest intencjonalnie opłacana grupa osób, która poprzez hejt ma wyeliminować konkurencję, zmniejszyć poparcie społeczne opozycji, czy napędzić klientów. Jest to również wykorzystywanie hejtu do celów propagandowych, szerzenia własnych racji, opinii i próby przebicia się ich poprzez negację odmiennych systemów wartości, przekonań i racji34. Jak twierdzi S. Kowalski, stanowi „instrument tzw. poprawności politycznej zmierzającej do zapewnienia bezkarności sobie i wyeliminowania ideowych przeciwników" 35 .

W tym miejscu winno się zwrócić uwagę na to, iż trudno jednoznacznie wskazać - kto, jaka grupa jest najbardziej narażona na działanie mowy nienawiści. Głównie, jak zostało już wspomniane, dotyka ona określone społeczności lub ich przedstawicieli36, jednak tak naprawdę problem ten może dotyczyć każdego ${ }^{37}$, bez względu na wiek, płeć, zajmowane stanowisko, status społeczny, narodowość, (nie)pełnosprawność, czy wyznawane wartości ${ }^{38}$.

Hejt niesie ze sobą szereg negatywnych konsekwencji, wśród których możemy wymienić izolację społeczną ${ }^{39}$, problemy w pracy, w szkole, zaburzenia odżywiania, depresję ${ }^{40}$, autoagresję, a niekiedy także i samobój-

${ }^{32}$ A. Gromkowska-Melosik, Tożsamość w cyber-przestrzeni, s. 38.

33 Tamże, s. 39.

34 Geneza hejtu, http://uprzedzuprzedzenia.org/czym-mowa-nienawisci/geneza-hejtu/, [dostęp: 15.10.2015].

35 S. Kowalski, Hate speech po polsku, [w:] Raport o homofobicznej mowie nienawiści w Polsce, red. G. Czarnecki, Warszawa 2009, s. 25-26.

${ }^{36}$ Raport o homofobicznej mowie nienawiści w Polsce, s. 8.

37 S. Kowalski, Hate speech po polsku, s. 25.

38 The Growth Of Cyberbullying, źródło: https://www.cybersmile.org/corporate, [dostęp: 15.10.2015].

${ }^{39}$ T. Leader, B. Mullen, D. Rice, Complexity and Valence in Ethnophaulisms and Exclusion of Ethnic Out-groups: What Puts the Hate into Hate Speech? Journal of Personality and Social Psychology, 2009, 96, s. 170.

40 Preventing and responding to hate crimes. A resource guide for NGOs in the OSCE region, Published by the OSCE's Office for Democratic Institutions and Human Rights, Warszawa 2009, s. 18. 
stwo ${ }^{11}$ (B. Mullen i J.M. Smyth przeprowadzili badania, w wyniku których okazało się, że w grupach mniejszościowych zagrożonych najbardziej dotkliwymi formami i treściami mowy nienawiści odnotowano najwyższy wskaźnik samobójstw ${ }^{42}$ ). Niesie ono również wiele negatywnych konsekwencji dla samych sprawców, gdyż jej przejawy są objęte odpowiedzialnością karną 33 , o czym świadczy m.in. art. 257 kodeksu karnego, zgodnie z którym: „Kto publicznie znieważa grupę ludności albo poszczególną osobę z powodu jej przynależności narodowej, etnicznej, rasowej, wyznaniowej albo z powodu jej bezwyznaniowości lub z takich powodów narusza nietykalność cielesną innej osoby, podlega karze pozbawienia wolności do lat $3^{\prime \prime 4}$.

Jak radzić sobie $\mathrm{z}$ hejtem? Pierwszym istotnym działaniem jest podnoszenie świadomości społecznej, monitorowanie oraz informowanie o skali i skutkach takiego zjawiska ${ }^{45}$. A. Stefaniak i M. Bilewicz zwracają uwagę, iż

wpływanie na zmianę takich poglądów może przebiegać dwutorowo. Z jednej strony, działając strukturalnie, powinno się wyrównywać status większości i mniejszości. Z drugiej zaś, poprzez edukację, budować przywiązanie do prawa (które zakazuje dyskryminacji i nienawiści) i zrozumienie negatywnych skutków mowy nienawiści dla szerszego społeczeństwa ${ }^{46}$.

Ważna jest odpowiednio wczesna interwencja oraz budowanie, za pomocą wszelkiego rodzaju akcji, szkoleń, kampanii, pozytywnego nastawienia i tolerancji wśród ludzi młodych ${ }^{47}$. W tym kontekście można przywołać stronę internetową www.komentujnieobrazaj.pl, która, poprzez m.in. kodeks kulturalnego komentowania, nawołuje do świadomego i pełnego szacunku wyrażania własnych opinii w przestrzeni online, bez dopuszczania się mowy nienawiści ${ }^{48}$. W przypadku zauważenia takich incydentów $\mathrm{w}$ przestrzeni Internetu, można zastosować premoderację przed upublicznieniem treści na blogach czy forach internetowych ${ }^{49}$ lub zgłosić nadużycie administratorowi strony za pomocą tzw. report buton i tym samym wpłynąć

${ }^{41}$ The Consequences, źródło: https://www.cybersmile.org/corporate, [dostęp: 15.10.2015].

42 B. Mullen, J.M Smyth, Immigrant Suicide Rates as a Function of Ethnophaulisms: Hate Speech Predicts Death, Psychosomatic Medicine, 2004, 66, s. 343-348.

43 Preventing and responding to hate crimes, s. 15.

${ }^{44}$ Ustawa z 6 czerwca 1997 roku, Kodeks Karny, art. 257. Inne artykuły KK traktujące o mowie nienawiści: art. 190, 196, 212, 216, 256.

45 Preventing and responding to hate crimes, s. 53.

${ }^{46}$ A. Stefaniak, M. Bilewicz, Polska: wyzwania. Mowa nienawiści, s. 85.

47 Tamże, s. 88.

48 Kodeks kulturalnego komentowania, źródło: http://www.komentujnieobrazaj.pl/kodekskulturalnego-komentowania, [dostęp: 15.10.2015].

${ }^{49}$ Mowa nienawiści w Internecie, s. 9 i 27. 
na usunięcie wpisu bądź zablokowanie użytkownika ${ }^{50}$. Ponadto, będąc ofiarami lub świadkami mowy nienawiści, zawsze mamy prawo do zawiadomienia organów policji o popełnieniu przestępstwa ${ }^{51}$.

Na stronie internetowej kampanii społecznej Love Has no Labels można znaleźć szereg wskazówek, jak radzić sobie z prześmiewczymi, pełnymi uprzedzeń i dyskryminacji praktykami w wielu miejscach, m.in. w środowisku pracy, domu, szkole, sąsiedztwie, w przestrzeni publicznej. Rozpatrywane jest to w dwóch kontekstach - bycia ofiarą hejtu, jak również obserwatorem takich zachowań. W przypadku osób doświadczających hejtu na własnej skórze, zalecana jest przede wszystkim racjonalna ocena sytuacji. Kiedy tylko zaistnieje realne zagrożenie spotęgowania agresji słownej względem osoby będącej ofiarą, należy unikać wdawania się $\mathrm{w}$ dyskusję $\mathrm{z}$ hejterem, gdyż może to stanowić dla niego bodziec, punkt zapalny do tego, aby jego agresja w stosunku do osoby atakowanej zwiększyła swą siłę i moc. Czasem warto powstrzymać się od komentarza i przemilczeć, aby dodatkowo nie sprowokować sprawcy. $W$ przypadku sytuacji, kiedy jesteśmy naocznymi świadkami zjawiska hejtingu, rady proponowane przez tę Kampanię w najogólniejszym ujęciu odnoszą się do rzeczowej rozmowy oraz polegają zawsze na werbalnym, jednoznacznym uświadomieniu o niewłaściwym zachowaniu i odczuciach towarzyszących tego typu przekazom. Otwarty głos w słusznej sprawie może stanowić wartościowy przyczynek, przysłowiową szczelinę, która być może uaktywni i ośmieli kolejne osoby, co w konsekwencji, pod ciśnieniem strumienia innych głosów, pomoże zburzyć mur społecznej nienawiści i obojętności52. Przykładem otwartej postawy społecznej przeciwko mowie nienawiści jest wypowiedź ucznia liceum (w postaci kilkuminutowego filmu) zamieszczona w serwisie YouTube (youtube.com). Dokonuje on otwartego sprzeciwu wobec dyskryminacji mniejszości (w szczególności uchodźców), wyrażając swoje niezrozumienie obecnej sytuacji społecznej i postuluje tym samym ocenianie innych indywidualnie, po uprzednim poznaniu ich historii, motywów, dążeń, wystrzegając się bezrefleksyjnego powielania zakorzenionych $\mathrm{w}$ świadomości społecznej stereotypów i uprzedzeń, mowy nienawiści oraz nawołuje do świadomego reagowania na nią. Jest to przykład otwartej postawy, prezentacji własnych myśli, odczuć i oceny sytuacji, a co najważniejsze - prezentowanej w sposób

50 Jak reagować na mowę nienawiści w sieci? źródło: http://www.siectolerancji.pl/jakreagowac/jak-reagowa\%C4\%87-na-mow\%C4\%99-nienawi\%C5\%9Bci-w-sieci, [dostęp: 15.10 . 2015].

51 A. Kwiecień, Co możemy zrobić, gdy zetkniemy się z mowa nienawiści? wyd. II, poprawione i rozszerzone, Warszawa 2011, s. 10-12.

52 Tips to fight bias and prejudice, http://lovehasnolabels.com/tips, [dostęp: 15.10.2015]. 
indywidualny i z zachowaniem szacunku dla obu stron ${ }^{53}$. (Temat hejtu, jak również podobną postawę prezentuje w Sieci wiele innych młodych osób, czego przykładem jest m.in kanał Matt Olech ${ }^{54}$ ).

Współcześnie powstaje coraz więcej organizacji, kampanii i akcji społecznych zajmujących się problematyką hejtu, przeciwdziałających mowie nienawiści. Przykładem może być stworzony przez Radę Europy program Young People Combating Hate Speech Online (Młodzi Ludzie Przeciw Mowie Nienawiści w Internecie) w latach 2012-2014, a w ramach niego koalicja - No Hate Speech Movement (Kampania Przeciw Mowie Nienawiści), zapoczątkowana w marcu 2013 roku ${ }^{55}$ czy Koalicja Przeciw Mowie Nienawiści w Polsce, wspierana przez Ministerstwo Edukacji Narodowej, która swoim zasięgiem obejmuje obecnie 82 instytucje i organizacje pozarządowe ${ }^{56}$.

Przykładem kolejnej organizacji przeciwdziałającej nadużyciom $\mathrm{w}$ cyberprzestrzeni jest wspomniana już organizacja non profit: The Cybersmile Foundation, która podejmuje szereg działań oscylujących wokół problemu przemocy $\mathrm{w}$ przestrzeni Internetu i szerzenia empatii $\mathrm{w}$ świecie online ${ }^{57}$. Oferuje m.in.: pomoc indywidualną za pośrednictwem skrzynki e-mailowej, chat dla osób doświadczających przemocy w Sieci, internetowe programy edukacyjne dla dzieci w różnym wieku, pakiet informacyjny o charakterze prewencyjnym i interwencyjnym dla rodziców, filmiki, zdjęcia, plakaty, możliwość posłuchania „pozytywnej listy przebojów”, jak również - co równie ważne - poznanie prawdziwych historii osób, które doświadczyły przemocy i hejtu w Sieci. Szczególnie wart zauważenia jest opublikowany przez nią film przestrzegający przed negatywnymi konsekwencjami hejtu. Jego bohaterka popełnia samobójstwo w wyniku morza negatywnych, destrukcyjnie oddziałujących na nią komentarzy i opinii, jakich doświadcza w przestrzeni Internetu, ukazanych jako sukcesywnie zaciskająca się pętla na jej szyi. A wszystko za sprawą opublikowanego w sieci filmiku, prezentującego wykonany przez nią cover popularnego utworu muzycznego ${ }^{58}$. Innym wartym zauważenia komunikatem medialnym jest film opublikowany

53 Człowiek imigrantom wilkiem, źródło: https://www.youtube.com/watch?v=aB2Wj TbZiPY\&feature=youtu.be, [dostęp: 15.10.2015].

54 MOWA NIENAWIŚCI - DWIE MINUTY POWAGI, https://www.youtube.com/ watch?v=C8vhjY50WPI, [dostęp: 15.10.2015].

55 No Hate Speech Movement. Campaign of Young People for Human Rights Online, źródło: http://www.nohatespeechmovement.org/, [dostęp: 15.10.2015].

56 Koalicja Przeciw Mowie Nienawiści, źródło: http://beznienawisci.pl/koalicja/, [dostęp:15.10.2015].

57 The Cybersmile Foundation, https://www.cybersmile.org/who-we-are, [dostęp: 15.10. 2015].

58 The Cybersmile Foundation 'Don't Retaliate', źródło: http://www.framestore.com/work/ cybersmile-foundation-dont-retaliate, [dostęp: 15.10.2015]. 
przez Fundację im. Stefana Batorego w ramach akcji Powiedz Stop Mowie Nienawiści. Prezentuje on grupę młodych ludzi, wśród których znajduje się młoda dziewczyna głośno komentująca w sposób negatywny dwóch spotkanych młodych mężczyzn. W miarę wypowiadania kolejnych obraźliwych słów, jej wygląd i sposób zachowania zaczyna do złudzenia przypominać Hitlera. Spot kończy pytanie „Serio, tak chcesz wyglądać?” To odważne porównanie i pytanie skierowane bezpośrednio do odbiorców zmusza do refleksji i stanowi wartą zauważenia metodę perswazji skierowaną do społeczeństwa, a w szczególności do młodych ludzi ${ }^{59}$, mającą za zadanie zachęcić do reagowania na takie przypadki. Wydaje się to szczególnie ważne, biorąc pod uwage fakt, iż na stronie Kampanii odnotowano 85596 wypowiedzi pełnych nienawiści znajdujących się w Sieci, jednak, póki co, tylko 3572 wy-

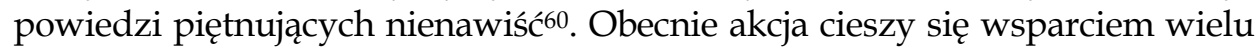
znanych osób: m.in. Rzecznika Praw Dziecka, Centrum Edukacji Obywatelskiej, Komedy Głównej Policji, Towarzystwa Edukacji Antydyskryminacyjnej i wielu innych ${ }^{61}$.

Kolejnym przykładem akcji społecznej walczącej z uprzedzeniami i mową nienawiści jest wspomniana już kampania: Love Has No Labels62. W ramach tej akcji na jednej z ulic umieszczono wielki czarny ekran, sprowadzający, za sprawą cyfrowej animacji, znajdujące się za nim postacie do wersji szkieletu (nie były one widoczne dla widzów). Każda para występujących bohaterów prezentowała, poprzez taniec oraz wyrazy swoich uczuć, różne oblicza miłości, po czym wychodziła z ukrycia i prezentowała się publice, powodując $\mathrm{w}$ ten sposób wiele pozytywnych uczuć i emocji. Wśród występujących znalazły się m.in. osoby niepełnosprawne, różnej płci i w różnym wieku, o różnym kolorze skóry, narodowości wyznawanej religii itp. Akcja ta ma na celu zwrócenie uwagi, że wszyscy jesteśmy równi, bez względu na płeć, pełnosprawność, religię, czy przekonania i w ten sposób przeciwdziałać dyskryminacji, etykietowaniu i stygmatyzowaniu mniejszości z uwagi na ich inność63.

W Polsce od 2013 roku aktywnie działa kampania HejtStop, prowadzona przez Stowarzyszenie „Projekt: Polska”. Na jej oficjalnej stronie internetowej odnajdujemy szereg informacji świadczących o jej szerokim zasięgu, do któ-

59 Powiedz stop mowie nienawiści, źródło: https://www.youtube.com/watch?v=N_ppto Mvdao\&feature=youtu.be, [dostęp: 15.10.2015].

60 Stop Mowie Nienawiści.

61 Stop Mowie Nienawiści - Kampanię wspieraja, źródło: http://stopmowienienawisci.pl/ kampanie-wspieraja/, [dostęp: 15.10.2015].

${ }^{62}$ Love Has No Labels, źródło: http:/ / lovehasnolabels.com/, [dostęp: 15.10.2015].

63 A bunch of skeletons kiss, hug, and dance in front of a crowd, https://www.youtube. com/watch?v=Cen7NhfpMVE, [dostęp: 15.10.2015]. 
rych należą takie cele, jak: walka z antysemityzmem, rasizmem, homofobią oraz „z każdą inną formą nienawiści”. Jej przedstawiciele łączą hejt nie tylko z mową nienawiści, ale również z wandalizmem ${ }^{64}$. Są oni inicjatorami ogólnopolskiego dnia zamalowywania napisów zawierających mowę nienawiści, do których przyłączają się przedstawiciele samorządów, władz, ambasadorzy, a także inne osoby publiczne i mieszkańcy miast. W tym roku 26. września malowano w Poznaniu, Katowicach, Bytomiu Łodzi, Koniecpolu, Ełku, Żywcu, Wadowicach, Gubinie, Gliwicach, Bydgoszczy oraz Świdnicy65. W ramach niniejszej akcji społecznej organizowane są dla wszystkich zainteresowanych warsztaty dotyczące mowy nienawiści, a na stronie internetowej Kampanii możemy odnaleźć z kolei scenariusze działań edukacyjnych, jak też „zgłosić hejta” poprzez zrobienie, a następnie wgranie zdjęcia (wraz z zaznaczeniem lokalizacji), które będzie podlegało usunięciu. O skali zjawiska świadczy fakt, iż na dzień 16. listopada br. na stronę wgrano już 1447 hejtów $^{66}$. Podobną ideę walki z mową nienawiści, w ramach zamalowywania dyskryminacyjnych i obraźliwych w swej treści napisów (a zastępowania ich pozytywnymi treściami i grafikami) urzeczywistnia Fundacja KLAMRA, w ramach akcji: „Mow@ Miłości” realizowanej od września 2014 roku67.

Do walki z mową nienawiści włączyło się wiele organizacji, m.in Centrum Edukacji Obywatelskiej, które poprzez program „Nienawiść-jestem przeciw", prowadzi szkolenia, warsztaty dla młodzieży gimnazjalnej oraz ponadgimnazjalnej i w ten sposób zachęca młodych ludzi do tworzenia własnych propozycji kampanii społecznych przeciwdziałających temu zjawi$\mathrm{sku}^{68}$. Także Stowarzyszenie Otwarta Rzeczpospolita prowadziło cykl warsztatów dla uczniów i nauczycieli przeciwdziałających mowie nienawiści „Zło może urosnąć - przeciw nienawiści”69. Na terenie naszego kraju prowadzone są także inne akcje, m.in. plebiscyty na „Szkołę Bez Nienawiści” i „Nauczyciela Bez Nienawiści” przez Fabrykę Równości ${ }^{70}$, a wszystko

64 Jak zamalowywać hejty? Podręcznik, s. 4., źródło: http://news.hejtstop.pl/wp-content/ uploads/2015/05/podrecznik_165x240_web.pdf, [dostęp: 15.10.2015].

${ }^{65}$ Kampania HejtStop, źródło: http://news.hejtstop.pl/, [dostęp: 15.10.2015].

66 Tamże.

67 Kampania „Mow@ Miłosci”, źródło: http://klamra.org/projekty/mow-milosci, [dostęp: 15.10.2015].

${ }^{68}$ Nienawiść - jestem przeciw! Centrum Edukacji Obywatelskiej, http://www.ceo.org.pl/pl/ mowanienawisci, [dostęp: 15.10.2015].

${ }^{69}$ Zto może urosnać - przeciw nienawiści - projekty edukacyjne 2011, http:/ / www.otwarta. org/jak-dzialamy/nasze-projekty/zlo-moze-urosnac-przeciw-nienawisci-projekty-eduka cyjne-2011/, [dostęp: 15.10.2015].

70 Szkoła bez nienawiści, źródło: http://fabrykarownosci.com/wptest/szkola-bez-niena wisci/, [dostęp: 15.10.2015]. 
$\mathrm{w}$ celu budowania tolerancji i niwelowania różnic społecznych poprzez upublicznianie i promowanie dobrych praktyk społecznych.

Na zakończenie pragnę przywołać słowa Michała Żakowskiego z zespołu HejtStop, zaczerpnięte ze strony Kampanii: „Media społecznościowe stają się współczesną wersją zakuwania w dyby - jedyna różnica jest taka, że kiedyś istniała jedna władza decydująca o tym, kto ma być ukarany. Dzisiaj chętnie urządzamy samosądy"71. Zjawisko hejtu wpisuje się w jedną ze współczesnych form wspomnianych samosądów i stanowi ważny współcześnie problem społeczny, który winniśmy sukcesywnie niwelować. Na szczęście i zarazem nieszczęście, wspomniane $w$ niniejszych słowach mass media nie stanowią jedynej formy komunikacji między ludźmi, co z jednej strony może prowadzić do ograniczenia tego procederu, zaś z drugiej strony nieść ryzyko przelania morza nienawiści na otoczenie wokół i stanowić przyczynek do tego, by dać upust swoim negatywnym emocjom $\mathrm{w}$ inny sposób. Istotne jest, żeby nieustannie zdawać sobie sprawę z tego, że słowa, język, przez który jesteśmy kształtowani, również może dotkliwie ranićp ${ }^{72}$.

Istota przeciwdziałania tego typu zjawiskom pozostaje zawsze taka sama - aby zmienić innych, należy zmienić siebie. Aby zmniejszyć zjawisko mowy nienawiści, warto prezentować pozytywne postawy - budować, tolerować, wspierać i pomagać - a wszystko po to, by ostatecznie dokonać zmiany (choćby częściowej) z postępującej cywilizacji hejtu w dającą poczucie bezpieczeństwa cywilizację szacunku i miłości.

\section{BIBLIOGRAFIA}

A bunch of skeletons kiss, hug, and dance in front of a crowd, https://www.youtube. com/watch?v=Cen7NhfpMVE, [dostęp: 15.10.2015].

Bilewicz M., Marchlewska M., Soral W., Winiewski M., Mowa nienawiści. Raport z badań sondażowych, Fundacja im. Stefana Batorego, Warszawa 2014.

Butler J., Walczace stowa, Wydawnictwo Krytyki Politycznej, Warszawa 2010.

Centrum Badania Opinii Spotecznej, Społeczna percepcja przemocy werbalnej i mowy nienawiśsi. Komunikat $z$ badań, Warszawa 2007 (BS/74/2007).

Człowiek imigrantom wilkiem, źródło: https://www.youtube.com/watch? $\mathrm{v}=\mathrm{aB2WjTb}$ ZiPY\&feature=youtu.be, [dostęp: 15.10.2015].

Czym jest mowa nienawiści, źródło: http://uprzedzuprzedzenia.org/czym-mowa-niena wisci/, [dostęp: 15.10.2015].

Dotknięci przez nienawiść, zapomniani przez prawo. Brak spójnego systemu zwalczania przestęstw z nienawiści w Polsce, Amnesty International 2015.

${ }^{71}$ Kampania HejtStop.

72 J. Butler, Walczace stowa, Warszawa 2010, s. 9-10. 
Foucault M., Trzeba bronić społeczeństwa, Wykłady w College de France 1976, przekł. M. Kowalska, Wydawnictwo KR, Warszawa 1998.

Geneza hejtu, http://uprzedzuprzedzenia.org/czym-mowa-nienawisci/geneza-hejtu/, [dostęp: 15.10.2015].

Gitari N.D., Zuping Z., Damien H., Long J., A Lexicon-based Approach for Hate Speech Detection, International Journal of Multimedia and Ubiquitous Engineering, 2015, 10, 4.

Gromkowska-Melosik A., Tożsamość w cyber-przestrzeni - (re)konstrukcje i (re)prezentacje, Kultura Współczesna, 1999, 3(21).

http://megahejt.pl/co-to-znaczy-hejt-i-hejter/, [dostęp: 15.10.2015].

Jak reagować na mowę nienawiści w sieci?, źródło: http://www.siectolerancji.pl/jak-reago wac/jak-reagowa\%C4\%87-na-mow\%C4\%99-nienawi\%C5\%9Bci-w-sieci, [dostęp: 15.10.2015].

Jak zamalowywać hejty? Podręcznik, s. 4., źródło: http://news.hejtstop.pl/wp-content/ uploads/2015/05/podrecznik_165x240_web.pdf, [dostęp: 15.10.2015].

Kampania HejtStop, źródło: http://news.hejtstop.pl/, [dostęp: 15.10.2015].

Kampania „Mow@ Miłosci”, źródło: http://klamra.org/projekty/mow-milosci, [dostęp: 15.10.2015].

Koalicja Przeciw Mowie Nienawiści, źródło: http://beznienawisci.pl/koalicja/, [dostęp:15.10.2015].

Kodeks kulturalnego komentowania, źródło: http://www.komentujnieobrazaj.pl/kodekskulturalnego-komentowania, [dostęp: 15.10.2015].

Kowalski S., Hate speech po polsku, [w:] Raport o homofobicznej mowie nienawiści w Polsce, red. G. Czarnecki, Wydawnictwo Kampania Przeciw Homofobii, Warszawa 2009.

Kowalski S., Tulli M., Zamiast procesu. Raport o mowie nienawiści, WAB, Warszawa 2003.

Krejtz K., Poziom kultury wypowiedzi internetowych i jego determinanty - wnioski z analizy treści wpisów polskich internautów, [w:] Internetowa Kultura Obrażania? red. K. Krejtz, Interactive Advertising Bureau Polska, Szkoła Wyższa Psychologii Społecznej, Ośrodek Przetwarzania Informacji, 2012, s. 25-26, źródło: http://www.komentujnie obrazaj.pl/kno/ko-raport.pdf, [dostęp: 15.10.2015].

Kwiecień A., Co możemy zrobić, gdy zetkniemy się z mowa nienawiści? wyd. II poprawione i rozszerzone, Warszawa 2011.

Law D.M., Shapka J.D., Hymel S., Olson B.F., Waterhouse T., The changing face of bullying: An empirical comparison between traditional and internet bullying and victimization, Computers in Human Behavior, 2012, 28.

Leader T., Mullen B., Rice D., Complexity and Valence in Ethnophaulisms and Exclusion of Ethnic Out-groups: What Puts the Hate into Hate Speech? Journal of Personality and Social Psychology, 2009, 96.

Love Has No Labels, źródło: http:/ / lovehasnolabels.com/, [dostęp: 15.10.2015].

McAfee, Teens and the Screen study: Exploring Online Privacy, Social Networking and Cyberbullying, 2014, źródło: http://www.mcafee.com/us/about/news/2014/q2/20140 603-01.aspx, [dostęp: 15.10.2015].

Mowa nienawiści, źródło: http://www.mowanienawisci.info/post/570/, [dostęp; 15.10.2015].

MOWA NIENAWIŚCI - DWIE MINUTY POWAGI, https://www.youtube.com/watch? $\mathrm{v}=$ C8vhjY50WPI, [dostęp: 15.10.2015].

Mowa nienawiści w Internecie. Jak z nia walczyć? Materiaty z konferencji, red. D. BychawskaSiniarska i D. Głowacka, Helsińska Fundacja Praw Człowieka, Warszawa 2013. 
Mullen B., Smyth J.M., Immigrant Suicide Rates as a Function of Ethnophaulisms: Hate Speech Predicts Death, Psychosomatic Medicine,2004, 66.

Nienawiść - jestem przeciw! Centrum Edukacji Obywatelskiej, http://www.ceo.org.pl/pl/ mowanienawisci, [dostęp: 15.10.2015].

No Hate Speech Movement. Campaign of Young People for Human Rights Online, źródło: http://www.nohatespeechmovement.org/, [dostęp: 15.10.2015].

Polska w ruchu. Eksperci i młodzi liderzy o wielokulturowości transformacji i aktywizmie, Warszawa 2014, s. 58-88, źródło: http://uprzedzuprzedzenia.org/wp-content/uploads/ 2015/08/Polska-w-Ruchu_PL.pdf, [dostęp: 15.10.2015].

Powiedz stop mowie nienawiści, źródło: https://www.youtube.com/watch?v=N_ppto Mvdao\&feature=youtu.be, [dostęp: 15.10.2015].

Preventing and responding to hate crimes. A resource guide for NGOs in the OSCE region, Published by the OSCE's Office for Democratic Institutions and Human Rights, Warszawa 2009.

Pyżalski J., Agresja elektroniczna dzieci i młodzieży - różne wymiary zjawiska, Kwartalnik Dziecko Krzywdzone, 2009, 1(26).

Raport o homofobicznej mowie nienawiści w Polsce, red. G. Czarnecki, Wydawnictwo Kampania Przeciw Homofobii, Warszawa 2009.

Recommendation No. R (97) 20 of The Committee of Ministers to Member States on "Hate Speech", Council of Europe, s. 107, źródło: http://www.coe.int/t/dghl/standard setting/hrpolicy/other_committees/dh-lgbt_docs/CM_Rec(97)20_en.pdf , [dostęp: 15.10.2015].

Ryłko E., Jak mówić o przestępstwach z nienawiści? [w:] Przemoc motywowana uprzedzeniami. Przestępstwa z nienawiści, red. A. Lipowska-Teutsch, E. Ryłko, Towarzystwo Interwencji Kryzysowej, Warszawa 2007.

Stefaniak A., Bilewicz M., Polska: wyzwania. Mowa nienawiści jako studium przypadku, [w:] Polska w ruchu. Eksperci i młodzi liderzy o wielokulturowości, transformacji i aktywizmie, Fundacja Humanity in Action Polska, Warszawa, 2014.

Stop Cyberbullying Day, Annual Research, 2015, https://www.cybersmile.org/wpcontent/uploads/Stop-Cyberbullying-Day-2015-Annual-Report.pdf, [dostęp: 15.10.2015].

Stop Mowie Nienawiści, źródło: http:/ / stopmowienienawisci.pl/, [dostęp: 15.10.2015].

Stop Mowie Nienawiści - Kampanię wspierają, źródło: http://stopmowienienawisci.pl/ kampanie-wspieraja/, [dostęp: 15.10.2015].

Szacka B., Wprowadzenie do socjologii, Oficyna Naukowa, Warszawa 2003.

Szkoła bez nienawiści, źródło: http://fabrykarownosci.com/wptest/szkola-bez-niena wisci/, [dostęp: 15.10.2015].

Tarapdar S., Kellett M., Young People's Voices On Cyberbulling: What can age comparisons tell us? Report 2011, D. Award, s. 25. źródło: http://oro.open.ac.uk/32271/1/Diana__Young_Peoples_Voices_Report.pdf, [dostęp: 15.10.2015].

The Consequences, źródło: https://www.cybersmile.org/corporate, [dostęp: 15.10.2015].

The Cybersmile Foundation, https://www.cybersmile.org/who-we-are, [dostęp: 15.10. 2015].

The Cybersmile Foundation, Corporate Partnership Programme 2015, s. 3, https://www. cybersmile.org/wp-content/uploads/Cybersmile-Corporate-Programme-20151.pdf, [dostęp; 15.10.2015].

The Cybersmile Foundation 'Don't Retaliate', źródło: http://www.framestore.com/work/ cybersmile-foundation-dont-retaliate, [dostęp: 15.10.2015]. 
The Growth of Cyberbullying, źródło: https://www.cybersmile.org/corporate, [dostęp: 15.10.2015].

Tips to fight bias and prejudice, http:/ / lovehasnolabels.com/tips, [dostęp: 15.10.2015].

Ustawa z 6 czerwca 1997 roku, Kodeks Karny, art. 257.

Weber A., Manual on hate speech, Council of Europe Publishing, Strasburg 2009.

Włodarczyk J., Mowa nienawiści w Internecie w doświadczeniu polskiej młodzieży, s. 3, źródło: http://www.mowanienawisci.info/wp-content/uploads/2014/10/Mowanienawi \% C5\%9Bci-w-internecie-w-do\% C5\%9Bwiadczeniu-polskiejm\%C5\%82odzie\%C5\%BCy.pdf, [dostęp: 15.10.2015].

Zto może urosnać - przeciw nienawiści - projekty edukacyjne 2011, http://www.otwarta. org/jak-dzialamy/nasze-projekty/zlo-moze-urosnac-przeciw-nienawisci-projektyedukacyjne-2011/, [dostęp: 15.10.2015]. 